https://doi.org/10.11646/zootaxa.4272.2.4

http://zoobank.org/urn:lsid:zoobank.org:pub:1B38C172-5A2C-478F-9836-5B25DB956261

\title{
The species of Hemiancistrus (Siluriformes: Loricariidae) from Ecuador
}

\author{
FRANCISCO PROVENZANO R..$^{1,2} \&$ RAMIRO BARRIGA S. ${ }^{1}$ \\ ${ }^{1}$ Instituto de Ciencias Biológicas, Escuela Politécnica Nacional, Quito Ecuador. \\ E-mail:fprovenz@gmail.com \& ramiro.barriga@epn.edu.ec \\ ${ }^{2}$ Centro Museo de Biología UCV, Instituto de Zoología y Ecología Tropical, Universidad Central de Venezuela. Caracas, Venezuela.
}

\begin{abstract}
At the Fish Collection of the Instituto de Ciencias Biológicas, Escuela Politécnica Nacional, Quito, three species traditionally grouped in the genus Hemiancistrus were identified: H. annectens (Regan 1904), H. landoni Eigenmann 1916, and a new specie described here. The new species inhabits exclusively in the Esmeraldas River Basin, Pacific slope, northwestern Ecuador. It is easily recognized by the completely naked abdomen, with rounded, dark spots, and a different color pattern on the dorsal and caudal fins. A comparative analysis of bones related to the opercular mobility, shows important differences between $H$. annectens, $H$. landoni, and the new species, suggesting that $H$. annectens does not belong to the genus Hemiancistrus or the Ancistrini group. According to the characteristics observed in these bones, H. annectens shows greater similarity to those reported in species of the Hypostomini group, supporting its inclusion in this group, but placing it in the genus Hypostomus requires further analysis. On the other hand, the conditions observed on the bones of Hemiancistrus landoni and the new species suggest that both are inside of the Ancistrini group. The new species is placed in the genus Hemiancistrus tentatively, pending future analysis.
\end{abstract}

\section{Resumen}

En la Colección de Peces del Instituto de Ciencias Biológicas, Escuela Politécnica Nacional, Quito se identificaron tres especies que tradicionalmente son agrupadas en el género Hemiancistrus: H. annectens (Regan 1904), H. landoni Eigenmann 1916, y una nueva especie que se describe aquí. La nueva especie habita exclusivamente en la cuenca del río Esmeraldas, vertiente del Pacífico, noroeste de Ecuador. Se reconoce fácilmente por presentar el abdomen completamente desnudo, con manchas oscuras redondeadas, y un patrón de color en las aletas dorsal y caudal diferente. Un análisis comparativo de los huesos relacionados con la movilidad del opercular muestra diferencias importantes entre $H$. annectens, $H$. landoni y la nueva especie, sugiriendo que $H$. annectens no pertenece al género Hemiancistrus y al grupo Ancistrini. Según las características observadas en dichos huesos, $H$. annectens muestra mayor similitud con las reportadas en especies del grupo Hypostomini, apoyando su inclusión en ese grupo, pero su colocación en el género Hypostomus requiere análisis adicionales. Por otra parte, las condiciones observadas en los huesos de H. landoni y la nueva especie sugieren que ambas están dentro del grupo Ancistrini. La nueva especie se coloca provisionalmente en el género Hemiancistrus, pendiente de análisis futuros.

Key words: fishes, taxonomy, systematic, freshwater, biodiversity

\section{Introduction}

The genus Hemiancistrus was created by Bleeker (1862) based on the species Ancistrus medians, described by Kner (1854), from Surinam. Since then, several species from different regions of South America have been included in this genus. The species come from the Guyana Shield, the Caribbean Sea Basin (Lake Maracaibo, Magdalena, Atrato), the Pacific slope of Panama, Colombia and Ecuador, the basins of the Uruguay River, the Tocantins River and other watersheds in southeastern Brazil (Kner 1854; Günther 1867; Regan 1904, 1913; Eigenmann 1916, 1918; Schultz 1944; Cardoso \& Malabarba 1999; Cardoso \& Lucinda 2003; Cardoso 2004; Cardoso \& Pezzi 2004; Werneke et al. 2005a, b; de Souza et al. 2008). Four species described from Ecuador, 
original or subsequently were placed in this genus, the four species were collected on the Pacific slope. In chronological order they are: Hemiancistrus annectens (Regan 1904), described from the Río San Javier and Rio Durango, Santiago River system, Esmeraldas Province. Hemiancistrus landoni Eigenmann 1916, described from Naranjito, Guayas River system. Hemiancistrus hammarlundi Rendahl 1937, described for Clementina River near Babahoyo, Guayas River system. Hemiancistrus hammarlundi is considered synonymous with $H$. landoni (Armbruster et al. 2015) and, Hemiancistrus fugleri Ovchynnyk 1971, described from the Bogota River, Cadondelet, Santiago river system, Esmeraldas, considered synonymous of $H$. annectens (Armbruster et al. 2015). Since 1999, there has been a remarkable increase in the number of species, mostly from Brazil and Venezuela (Cardoso \& Malabarba 1999; Cardoso \& Lucinda 2003; Cardoso 2004; Cardoso \& Pezzi 2004; Werneke et al. 2005a, b; Lujan \& Chamon 2008; de Souza et al. 2008). Hypotheses of phylogenetic relationships inside the subfamily Hypostominae (Armbruster 2004, 2008; Covain \& Fisch-Muller 2012; Lujan et al. 2015) point out that some of the species in the genus Hemiancistrus show close relationships with species of the genera Hypostomus, Pterygoplichthys, Pseudancistrus, Baryancistrus, Hypancistrus, and Peckoltia. Therefore, Armbruster (2004, 2008) put some species in the genus Pseudancistrus or in a new genus not described, inside Pterygoplichthyini group. Recently, Armbruster et al. (2015) highlight the taxonomic complexity of Hemiancistrus and consider that H. medians is the only valid species of Hemiancistrus. They use the results obtained by Lujan et al. (2015), and transferred to the genus Hypostomus, the species H. aspidolepis, H. annectens, H. maracaiboensis, and H. wilsoni. Propose three species groups, 'H.' chlorostictus group for 'H.' cerrado, 'H.' chlorostictus, 'H. 'fuliginosus, 'H.' megalopteryx, 'H.' meizospilos, 'H. ' punctulatus, and 'H.' votouro, 'H.' 'landoni group with only 'H.' landoni, and the 'H.' guahiborum group, with 'H.' guahiborum and 'H.' subviridis. Armbruster et al. (2015) established that $H$. fugleri and, $H$. hammarlundi are synonyms of $H$. annectens and, $H$. landoni respectively. Finally, they place $H$. micrommatos, H. spinosissimus and H. spilomma in genus Ancistomus, Hemiancistrus pankimpuju in genus Peckoltia, and H. macrops as synonym of 'Pseudancistrus' megacephalus. This arrangement determines that Hemiancistrus sensu stricto has a single species, H. medians and there are 10 or more species with an uncertain status at the genus level. On the other hand, the holotype of Hemiancistrus medians is lost and some debate arises about the precise identity of the species and the type of the genus. Fisch-Muller et al. (2012) analyzed this problem and established a neotype and, a new redescription for H. medians. Before, Günther (1864) based on two specimens, presented a description of H. medians, and he indicates that there is no doubt that these specimens are identical to those described by Kner (1854), although the two specimens have a partially covered abdomen. Günther stated that the specimens were sent to London by the same person who sent them to Stuttgart, Mr. Kappler. Regan (1904) presented another description using the same specimens of Günther (1864), and gave a clear description of the abdominal covering on the adult specimen. These two descriptions agree with the redescription of Fisch-Muller et al. (2012).

There are three morphotypes of Hemiancistrus group in western drainages in Ecuador, H. annectens, $H$. landoni, and a third species, whose external morphological characteristics do not match with those observed in the species included in Hemiancistrus sensu lato or with those indicated in the original descriptions of $H$. hammarlundi, and H. fugleri. In this paper, the new species is described, and is tentatively located in the genus Hemiancistrus ('H.' landoni group), additionally some data from Hypostomus annectens and Hemiancistrus landoni are included. A phylogenetic analysis between species grouped in the family Loricariidae, mostly in Hypostominae, was performed using osteological analysis (Schaefer 1987, Armbruster 2004 2008). In order to bring additional data about generic allocations of the three species studied, a comparative analysis of the bones related to the mobility of the opercular is presented.

\section{Material and methods}

The Fish Collection (MEPN), Ichthyology Section, Instituto de Ciencias Biológicas of the Escuela Politécnica Nacional, in Quito, has 35 cataloged lots of species traditionally included in the genus Hemiancistrus. The species identifications were made using the original descriptions and figures, and in some cases other additional references and figures were used, and when possible were compared with specimens from the type localities. For comparisons and identifications, morphological, morphometric and meristic data were taken, on a variable number of specimens. Observations, measurements and counts were performed using a Zeiss, Stemi 1000 stereomicroscope 
and an analogic Mitutoyo calipers. Measurements and counts were those proposed by Boeseman (1968). Measurements are expressed as percentage of standard length. Dry skeletons (Provenzano \& Nass, in prep.) of each species were prepared for comparison of bones related to the mobility of the opercular region. The locality of each of the lots identified is established to know the geographical distribution of species.

\section{Results}

The analysis of the MEPN fish collection, shows that three species traditionally included in the genus Hemiancistrus, are recognizable. The external morphology, the color pattern and the having a dentary angle greater than $90^{\circ}$ suggest they are more similar to species included in Hypostomus (H. annectens) or Hemiancistrus (H. landoni and a new species). These species inhabit solely Pacific Ocean drainages. The first species is $H$. annectens (Regan 1904) collected exclusively in the Santiago River basin, province of Esmeraldas, northern Ecuador. The second species is H. landoni Eigenmann 1916, collected in the Guayas, Arenillas, Puyango and Zaracay Rivers, provinces of Manabi, Los Rios, Guayas and El Oro. The third species inhabits only the Esmeraldas River basin, provinces of Pichincha and Esmeraldas, its external characteristics don't match with the original descriptions of all other species in the genus Hemiancistrus sensu lato (Armbruster et al. 2015) or with the original descriptions of $H$. fugleri Ovchynnyk 1971 and $H$. hammarlundi Rendahl 1937. Therefore, it is considered a new species, named here as Hemiancistrus furtivus n. sp.

\section{Key to the species commonly referred to as Hemiancistrus in Ecuador}

1a Cheek region with four to eight, small, scarcely developed odontodes, visible mostly on adult specimens. These odontodes are associated with a bony plate, with reduced mobility or immobile. Dorsal fin folded reaches the origin of adipose fin in juveniles, or very close in adults. Caudal fin furcate. Santiago River Basin, province of Esmeraldas, NW of Ecuador ..........

Hypostomus annectens

$1 \mathrm{~b}$ Cheek region with 12 or more developed odontodes, very small in juveniles. These odontodes are associated with connective tissue, they are located behind a bony plate or bony granulations, and are always mobile. Dorsal fin folded does not reach adi-

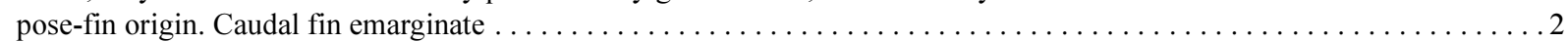

2a Ventral surface of the head and abdomen covered with small plates or granulations in specimens with $80 \mathrm{~mm}$ SL or more. Cheek odontodes 15 or more, well developed, longest (most posterior) greater than eye diameter. Dorsal fin with rounded dark dots arranged in vertical lines just in the middle of interradial membrane. Guayas, Arenillas, Puyango and Zaracay Rivers systems, provinces of Manabí, Los Rios, Guayas and El Oro . . . . . . . . . . . . . . . . . . Hemiancistrus landoni

$2 \mathrm{~b}$ Ventral surface of the head and abdomen completely naked in specimens $85 \mathrm{~mm}$ SL. Cheek odontodes $12-15$, very few developed, longest less than eye diameter. Dorsal fin with irregular dark dots arranged in vertical lines on the interradial membrane close to the rays. Esmeraldas river system, provinces of Pichincha and Esmeraldas. Hemiancistrus furtivus

\section{Hemiancistrus furtivus new species}

Tables $1 \& 2$, Figures $1 \& 2$

Holotype. MEPN 11569, 83.0 mm SL, Ecuador, Pichincha Province, Esmeraldas River Basin, Río Silanche, río Blanco tributary, close to San Francisco de Silanche town, approx. $00^{\circ} 08^{\prime} 45^{\prime \prime} \mathrm{N} 79^{\circ} 16^{\prime} 38^{\prime \prime} \mathrm{W}$, R. Barriga S. and A. Villacis, 07 November 2005, RBS05-24.

Paratypes. All from Ecuador, Esmeraldas River Basin: MEPN 18411, 1 ex., $99.8 \mathrm{~mm} \mathrm{SL}$, Same data as holotype. MEPN 4475, 1 ex., 79.2 mm SL, C\&S, Esmeraldas Province, Estero Chipo a $11 \mathrm{~km}$ de Quinindé, vía Golondrinas-Buenos Aires, afluente del Río Blanco, approx. 00¹6'28"N 79²4'11"W, R. Barriga, and C. Cerón, 13 March 1985, RBS85-96. MEPN 4488, 1 ex., mm SL, Esmeraldas Province, Estero Mendoza, in front to Estero

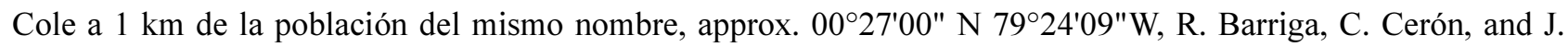
Caicedo, 10 March 1985, RBS85-91. MEPN 11421, 1 ex., 54.4 mm SL, Esmeraldas Province, Río Quinindé. $00^{\circ} 18^{\prime} 49^{\prime \prime N} 79^{\circ} 29^{\prime} 01^{\prime \prime W}$, R. Barriga S. and A. Villacis, 05 November 2005, RBS05-29. MEPN 11497, 1 ex., 70.3 $\mathrm{mm}$ SL, Esmeraldas Province, Río Chamba, a $5 \mathrm{~km}$ de la vía Quinindé-Esmeraldas, approx. $00^{\circ} 15^{\prime} 04^{\prime \prime} \mathrm{N}$ 79²1'07"W, R. Barriga S. and A. Villacis, 01 November 2005, RBS05-25. MCZ 48772, 13 ex., (12 Alc. 1 C\&S), 55-97 mm SL, Esmeraldas Province, Río Tabuche, (Riachuelo) $49 \mathrm{~km}$ SE Esmeraldas, approx. 0043'07"N 
79³2'57"W, T. Roberts, C. Gilbert, and M. Silva, 20 October 1971. AUM 4242 (out MCZ 48772), 1 ex., 75.7 mm SL, same data MCZ 48772. MEPN-19058 (out MCZ 48772), 2 ex., (1 Alc. 1 C\&S), 88.3-100.5 mm SL, same data MCZ 48772.

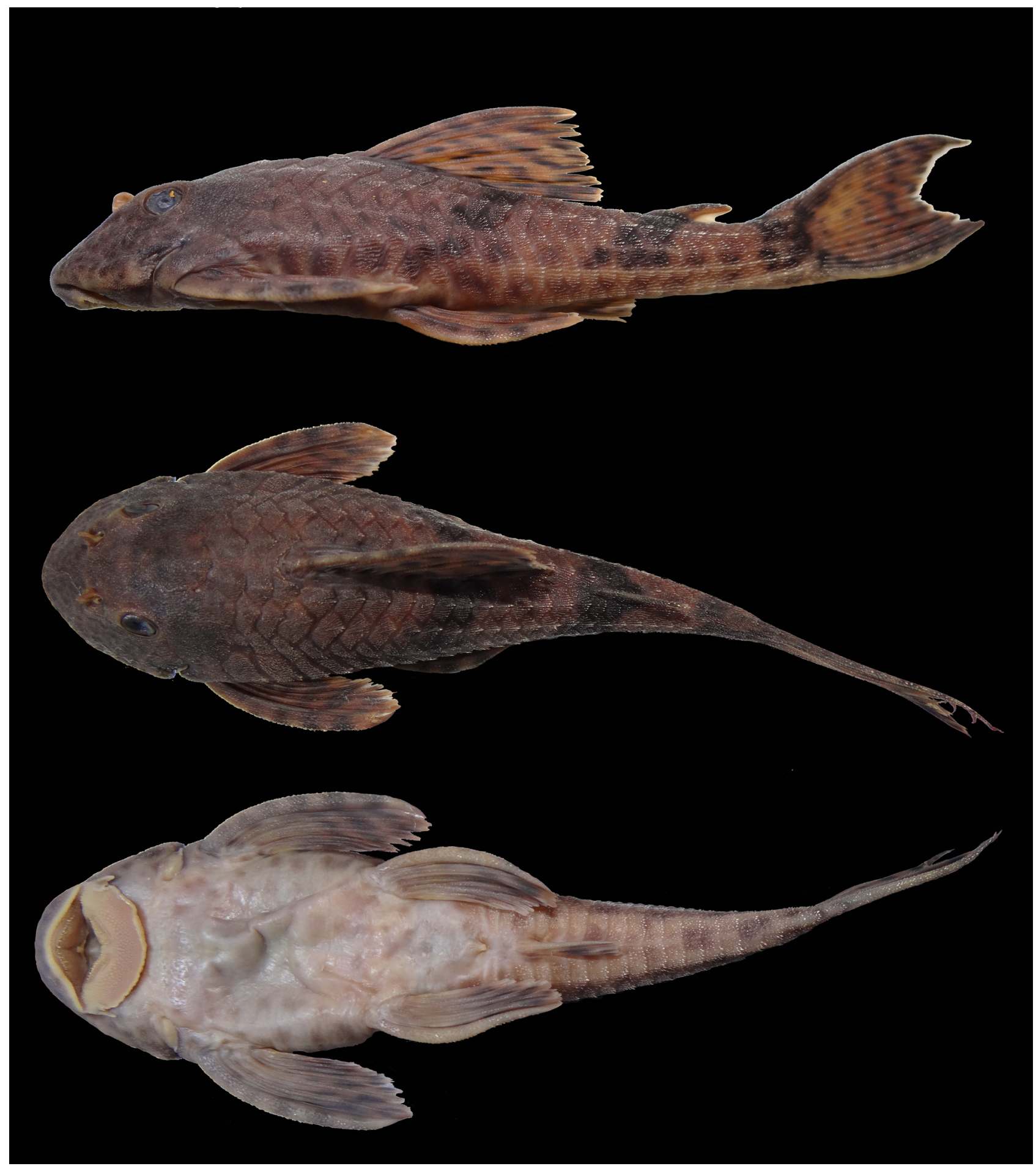

FIGURE 1. Hemiancistrus furtivus, in lateral, dorsal, and ventral view. MEPN 11569, holotype, 83.0 mm SL.

Diagnosis. Hemiancistrus furtivus is distinguished from its unique geographical congener H. landoni and from H. medians by the totally naked abdomen and the color pattern of the dorsal and caudal fins. The dorsal fin has vertical rows of nearly rounded spots, dark (black or brown), on the interradial membranes, very near or attached to the rays, in $H$. landoni the dorsal fin has vertical rows of dark dots in the middle of the interradial membrane (Fig. 2), while in $H$. medians the dorsal fin has vertical rows of dark dots on the interradial membrane near and, over the 
rays. In $H$. furtivus, the dots are smaller, near the diameter of eye or less, whereas the dots are greater than eye diameter in H. landoni and H. medians. On the caudal fin, H. furtivus has transverse rows of spots nearly rounded, dark (black) randomly dispersed on the interradial membrane and rays, mostly on the distal area, where they have the appearance of transverse dark bands. In $H$. landoni, the caudal fin color pattern is similar to the dorsal fin. In $H$. furtivus there are between 12-15 cheek odontodes, each odontode emerges from a fleshy sheath, only its tip protrudes and is visible, the length of the longest odontode is less than eye diameter. In H. landoni there are more than 15 cheek odontodes, with a similar condition as H. furtivus, but around half of each odontode is visible, the length of longest (most posterior) is greater than the eye diameter. The new species can be recognized from all other species of Hemiancistrus sensu lato (Armbruster et al. 2015) except H. medians and H. landoni by the presence of dark rounded dots on the belly $v s$. belly whitish or with pale color homogeneous, without dots or spots. Finally, the species grouped in the 'H. ' chlorostistus group from Brazil have patches of small plates on the abdomen while $H$. furtivus has the abdomen completely naked.

TABLE 1. Morphometric data of Hemiancistrus furtivus. Measurements are expressed as percentage of standard length. $\mathrm{N}=5$.

\begin{tabular}{|c|c|c|c|c|c|}
\hline Character & Holotype & Average & STD & Min. & Max. \\
\hline $\mathrm{SL}(\mathrm{mm})$ & 83.0 & & & 54.4 & 99.8 \\
\hline Head length & 31.9 & 31.8 & 1.0 & 30.4 & 33.0 \\
\hline Predorsal length & 40.0 & 39.3 & 0.9 & 37.9 & 40.0 \\
\hline Postdorsal length & 42.7 & 42.5 & 0.9 & 41.4 & 43.9 \\
\hline Interdorsal length & 21.3 & 20.6 & 1.3 & 19.5 & 22.6 \\
\hline Preanal length & 63.1 & 62.8 & 0.7 & 61.7 & 63.8 \\
\hline Postanal length & 36.6 & 34.9 & 1.2 & 33.3 & 36.6 \\
\hline Thoracic length & 25.9 & 24.5 & 0.8 & 23.9 & 25.9 \\
\hline Abdominal length & 20.8 & 20.0 & 0.9 & 19.0 & 21.0 \\
\hline Dorsal fin base & 22.9 & 22.6 & 0.9 & 21.1 & 23.4 \\
\hline Dorsal spine length & 29.1 & 27.6 & 1.3 & 25.9 & 29.1 \\
\hline Pectoral spine length & 30.1 & 29.0 & 0.7 & 28.2 & 30.1 \\
\hline Pelvic spine length & 23.4 & 23.0 & 0.7 & 21.9 & 23.5 \\
\hline Cleithral width & 28.7 & 28.4 & 0.3 & 28.1 & 28.7 \\
\hline Caudal peduncle depth & 8.5 & 8.6 & 0.1 & 8.5 & 8.8 \\
\hline Head depth & 18.5 & 17.5 & 0.8 & 16.4 & 18.5 \\
\hline Snout length & 18.5 & 17.9 & 0.6 & 17.2 & 18.5 \\
\hline Interorbital width & 10.9 & 11.0 & 0.4 & 10.7 & 11.6 \\
\hline Orbital diameter & 6.0 & 5.8 & 0.2 & 5.6 & 6.0 \\
\hline Mandibular ramus length & 4.9 & 4.8 & 0.1 & 4.6 & 4.9 \\
\hline
\end{tabular}

Description. Morphometric data given in Table 1. Body robust, progressively compressed posteriorly. Caudal peduncle compressed, deep and robust. Dorsal profile of body from tip of snout through eyes, straight, with a slope close to $45^{\circ}$, from eyes to dorsal-fin origin gently convex, then gradually descending straight to caudal-fin origin. Ventral profile of body flat and straight or slightly concave. Ventral surface of head and belly naked to anus. From the anus to anal-fin origin, a straight naked band is present bordered by end of lateral plates. Urogenital papilla absent, the cloaca is a small but evident fleshy tube. Head wide and little depressed. Snout not projected with naked, oval tip. Eyes in dorsolateral position, orbits raised. Interorbital space broad. Supraoccipital slightly convex, posterior border rounded. 
TABLE 2. Comparative morphometric data for Hemiancistrus furtivus, $\mathrm{N}=5$, and H. landoni $\mathrm{N}=5$.

\begin{tabular}{|c|c|c|c|c|}
\hline & \multicolumn{2}{|c|}{ H. furtivus } & \multicolumn{2}{|c|}{ H. landoni } \\
\hline & Min. & Max. & Min. & Max. \\
\hline $\mathrm{SL}(\mathrm{mm})$ & 54.4 & 99.8 & 56.3 & 86.5 \\
\hline Character & Average & STD & Average & STD \\
\hline Head length & 31.8 & 1.0 & 32.7 & 1.2 \\
\hline Predorsal length & 39.3 & 0.9 & 39.4 & 1.2 \\
\hline Postdorsal length & 42.5 & 0.9 & 41.2 & 1.3 \\
\hline Interdorsal length & 20.6 & 1.3 & 21.8 & 1.3 \\
\hline Preanal length & 62.8 & 0.7 & 63.0 & 0.4 \\
\hline Postanal length & 34.9 & 1.2 & 33.8 & 0.9 \\
\hline Thoracic length & 24.5 & 0.8 & 22.9 & 0.6 \\
\hline Abdominal length & 20.0 & 0.9 & 19.7 & 0.6 \\
\hline Dorsal fin base & 22.6 & 0.9 & 22.5 & 1.3 \\
\hline Dorsal spine length & 27.6 & 1.3 & 28.7 & 1.0 \\
\hline Pectoral spine length & 29.0 & 0.7 & 29.7 & 1.2 \\
\hline Pelvic spine length & 23.0 & 0.7 & 25.0 & 0.5 \\
\hline Cleithral width & 28.4 & 0.3 & 30.3 & 0.7 \\
\hline Caudal peduncle depth & 8.6 & 0.1 & 9.1 & 0.2 \\
\hline Head depth & 17.5 & 0.8 & 18.4 & 0.6 \\
\hline Snout length & 17.9 & 0.6 & 18.7 & 0.4 \\
\hline Interorbital width & 11.0 & 0.4 & 11.5 & 0.6 \\
\hline Orbital diameter & 5.8 & 0.2 & 6.3 & 0.6 \\
\hline Mandibular ramus length & 4.8 & 0.1 & 4.6 & 0.5 \\
\hline
\end{tabular}

Cheek mobile odontodes $12-15$, tiny and thin. Each odontode arises from fleshy cylindrical base, and only tip protrudes. Tips orange or amber. Mobile odontodes roughly arranged in rosette pattern. Opercular bone exposed, visible externally, its lateral margin with small odontodes.

Mouth oval or rounded. Upper lip narrow, usually covering premaxilla and only external surface is visible, edge is almost horizontal with very minute undulations. Internal surface papillose. Lower lip broad, its border crenulated. Lower lip surface papillose. Papillae smaller near border of lip increasing in size near lower jaws. Papillae of anterior lip similar in size to those near lower jaws. Maxillary barbels short, united to lower lip, leaving only tip free. Premaxilla slightly longer than dentary. Premaxillae nearly straight forming $\sim 180^{\circ}$ angle. Dentaries separate, forming open "V" between them, with angle $95^{\circ}-105^{\circ}$ between rami. Teeth numerous and minute, $25-35$ teeth in each hemimandible. Premaxillary and dentary teeth of same size. Teeth incisor type, asymmetrically bifid, medial cusp longer and wider than lateral cusp. Medial cusp rounded or straight truncated, lateral cusp pointed. Tooth apex curved toward interior of mouth. Tooth apex yellowish, stalk whitish. Premaxillary and dentary with posterior small papillae.

Plates on sides of body with keels. Lateral line plates 27 or 28. Post-anal plates 15 or 16. Inter-dorsal plates seven or eight, just in front of adipose-fin soine one small plate with keel. Dorsal-fin origin anterior to vertical passing through pelvic-fin origin. Dorsal-fin with one spinelet, one spine, and seven branched rays; when depressed tip does not reach adipose-fin origin. Adipose-fin well developed and always present. Spine of adipose fin wide, and straight. Pectoral-fin with one spine, and six branched rays. When depressed, pectoral-fin spine reaches less than one third of pelvic-fin spine length. Spine of pectoral-fin with a fleshy tip, and slightly shorter than first branched ray. Pelvic-fin with one spine and five branched rays; its posterior margin surpassed anal-fin base when depressed. Anal-fin with one flexible spine and four branched rays. Caudal-fin rays i,14,i. Caudal-fin emarginate. 


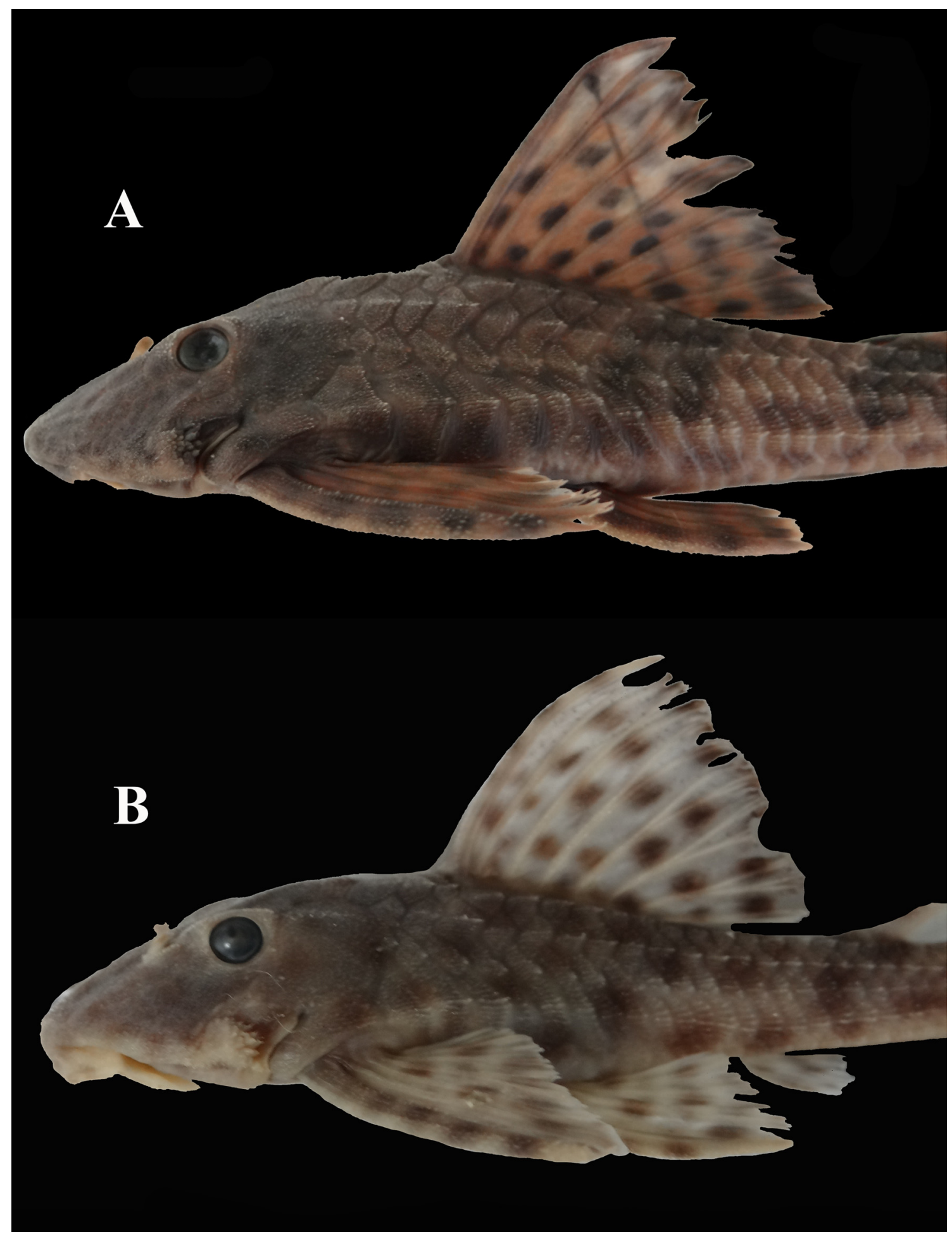

FIGURE 2. Partial lateral view of A) Hemiancistrus furtivus, MEPN 18411, $99.8 \mathrm{~mm}$ SL, and B) H. landoni, MEPN 17952 , $78.9 \mathrm{~mm} \mathrm{SL}$.

Color. Specimens preserved in 70\% ethanol show little variation in base color. General color of head and dorsolateral surfaces of body dark brown. Dark (black), rectangular, ovals or rounded spots, of different sizes, and randomly arranged on head and body. Spots became smaller, concentrated, and faint or diffuse on snout. Two or three transverse, dark (black), and irregular saddles, anteriorly oriented, first at end of dorsal-fin base, second at adipose fin origin, and last at caudal-fin origin; saddles more visible in dorsal view. Patch of dark spots at caudalfin origin. Base color of abdomen uniform, creamy or whitish, with irregular, dark (black) spots. Dorsal fin with longitudinal rows of nearly rounded spots, dark (black or brown), on interradial membrane, near or attached to the 
rays. Caudal fin with transverse rows of spots nearly rounded, dark (black) randomly dispersed on interradial membrane and rays, mostly at distal area, where they appear to combine in transverse dark bands. Rest of fins with brown base color with dark (black) spots on spines, branched rays and interradial membranes (Figs. 1-2). Smallest specimen (54.4 mm SL) with dorsal and caudal fins with longitudinal or transverse, respectively, dark bands.

Geographical distribution. The specimens were caught in the Esmeraldas River Basin, Provinces of Esmeraldas and Pichincha (Fig. 5).

Etymology. The name of the species is taken from the Latin word furtivus meaning: attempting to pass unnoticed or hidden, and alludes to the fact that the species was not detected before despite being in the Ecuadorian Pacific region, one of the best known ichthyologically. An adjective.

\section{Hypostomus annectens (Regan 1904)}

Figure 3

Ancistrus annectens Regan, 1904: 225, pl. 11 (fig. 2). Type locality: St. Javier and the Rio Durango, N. W. Ecuador. Hemiancistrus annectens (Regan 1904), Eigenmann, 1910; Isbrücker 1980; Fisch-Muller 2003; Ferraris, 2007.

Hemiancistrus fugleri Ovchynnyk 1971:108, Figs. 12-15. Type locality: Río Bogota, Parroquia Cadondelet, $1^{\circ} 06^{\prime} \mathrm{N}, 78^{\circ} 45^{\prime} \mathrm{W}$, Province Esmeraldas, Ecuador.

Hypostomus annectens (Regan 1904), Armbruster et al. 2015

Material examined. All from Ecuador, Esmeraldas Province, Santiago River Basin. MEPN-3423, 3 ex., 43.0-75.2 mm SL, Puerto Libre, río San Miguel, Manuel Olalla, February 1969. MEPN-4080, 1 ex., 69.6 mm SL, Río Toachi, cerca de Santo Domingo de los Colorados, km 6 de la vía a Esmeraldas, J. Ayala et al., 14 September 1967. MEPN4262, 1 ex., $40.7 \mathrm{~mm}$ SL, Estero Chapiro, a $1 \mathrm{~km}$ de la desembocadura del río San Miguel en el río Cayapas, R. Barriga et al., 24 September 1984. MEPN-4263, 1 ex., $37.01 \mathrm{~mm}$ SL, Estero Chapiro, a $1 \mathrm{~km}$ de la desembocadura del río San Miguel en el río Cayapas, R. Barriga et al., 24 September 1984. MEPN-4265 1 ex., 152.8 mm SL, Río Cayapas, a $2 \mathrm{~km}$ aguas abajo de la casa del MAG, R. Barriga et al., 22 September 1984. MEPN-4489, 2 ex., 89.4$95.5 \mathrm{~mm}$ SL, Estero La Comunidad, a 20 minutos aguas arriba de la boca del río Onzole, approx. 0057'54"N 7900'48"W, R. Barriga \& R. León, 19 August 1985. MEPN-12779, 1 ex., 214.1 mm SL, Estero La Comunidad, a 20 min aguas arriba de la boca del Onzole, approx. 00 $57^{\prime} 54^{\prime \prime N} 79^{\circ} 00^{\prime} 48^{\prime \prime} \mathrm{W}$, R. Barriga, 20 August 1985. MEPN17951, 3 ex., 163.8-175.2 mm SL, Muelle campamento forestal, approx. 0104'39"N 7859'38"W, R. Barriga, 10 August 1995.

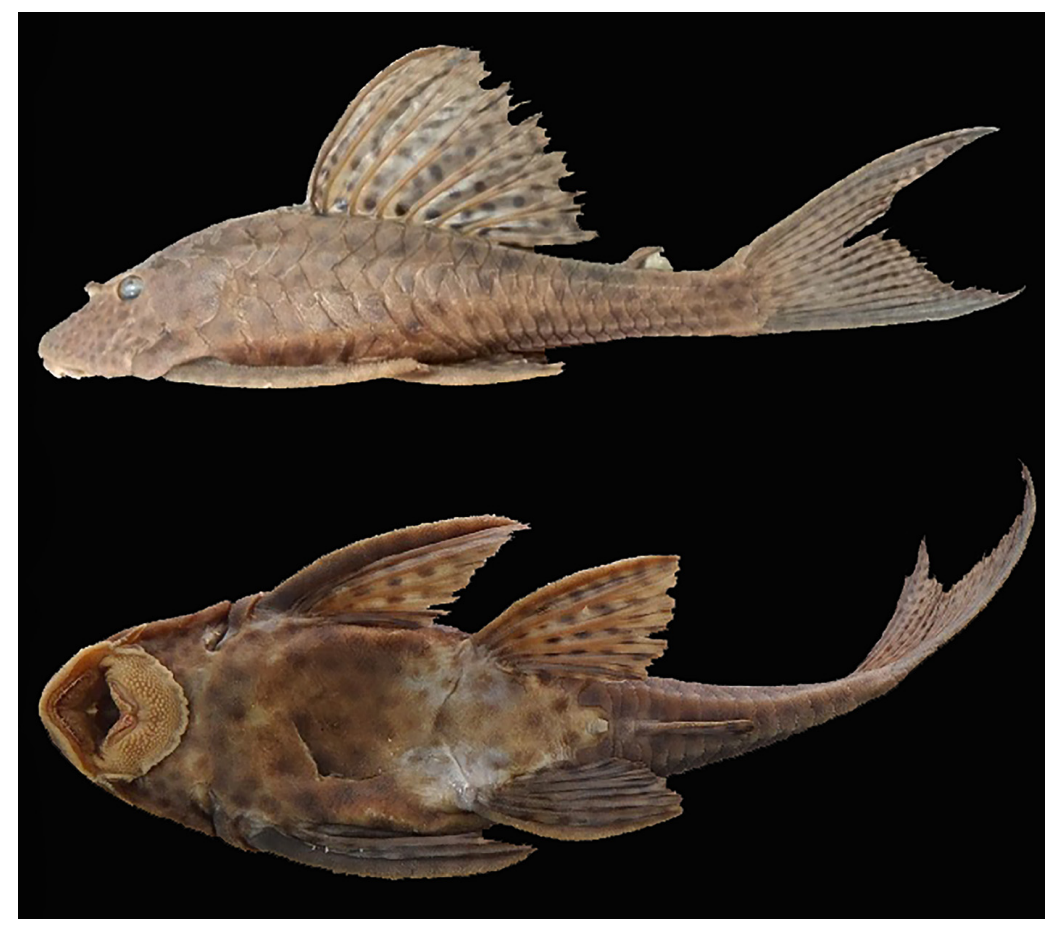

FIGURE 3. Lateral and ventral view of Hypostomus annectens, MEPN 17951, $163.8 \mathrm{~mm}$ SL. 
Hypostomus annectens has fourteen branched rays on caudal fin, and seven branched rays on dorsal fin. The caudal fin is furcate or markedly emarginate. The dorsal fin depressed reaches the origin of the adipose fin, in juveniles; in adults it does not reach, but is very close. The adipose fin is always present. The abdomen is almost completely covered, in adults; there are naked areas in front and in the inner side of the pelvic fins. Juveniles, have small plates on the ventral region of the head, at the level of the pectoral girdle, and sides of the abdomen, but the central region of the abdomen until behind the anus is complete naked. The species has few cheek odontodes (4-8), somewhat developed (straight, and thick compared with normal odontodes). The cheek odontodes are associated with a bony plate with reduced mobility or immobile. The color of the body and fins is brown with rounded dark or black spots. The spots on the caudal fin are smaller than in the rest of the body and fins. The abdomen has dark rounded spots. The species inhabits the Pacific slope, in NW Ecuador, exclusively in aquatic systems draining the river Santiago, Province of Esmeraldas.

\section{Hemiancistrus landoni Eigenmann 1916}

Figure 4

Hemiancistrus landoni Eigenmann 1916:84. Type locality: Naranjito, Ecuador.

Hemiancistrus hammarlundi Rendahl 1937:2, Fig. 1. Type locality: Río Clementina system, northwest of Babahoyo, Los Ríos, Ecuador.

Material examined. All from Ecuador, El Oro Province, MEPN-5948, 1 ex., $171.5 \mathrm{~mm}$ SL, La Cuca, canal de riego, río Arenillas, Granja PREDESUR, approx. 0330'00"S 8004'20"W, R. Barriga et al., 13 April 1979. MEPN5954, 1 ex., $88.6 \mathrm{~mm}$ SL, Río Piedras, curso superior del río Arenillas, approx. $03^{\circ} 38^{\prime} 10^{\prime \prime S} 79^{\circ} 55^{\prime} 40^{\prime \prime} \mathrm{W}$, R. Barriga et al., 12 April 1979. MEPN-17505, 1ex. 68.7 mm SL, Río Zaracay, approx. 03³8'55"S 7952'180"W, P. Tufiño \& R. Barriga, 20 November 2010. Guayas Province, MEPN-9820, 1 ex., 59.9 mm SL, Río Minas, donde cruza la cooperativa 23 de Noviembre, $9 \mathrm{~km} \mathrm{~S}$ de Naranjal, approx., 02 $41^{\prime} 26^{\prime \prime S} 79^{\circ} 38^{\prime} 16^{\prime \prime} \mathrm{W}$, R. Barriga, 22 September 1992. MEPN-15118, 1 ex., 134.9 mm SL, Río Minas, donde cruza la cooperativa 23 de Noviembre, $9 \mathrm{~km} \mathrm{~S} \mathrm{de}$ Naranjal, approx., 0241'26"S 79³8'16"W, R. Barriga, 22 September 1992. Los Ríos Province, MEPN-9926, 8 ex. (7 Alc. 1 Dry skeleton), 128.4-205.8 mm SL, Río Catarama, cerca de la poblacion Corona, approx. 01³7'23"S 79²8'20"W, R. Barriga, 15 February 1997. MEPN-10389, 1 ex., 214.6 mm SL, Río Quevedo, approx. 0102'04"S 79²7'43"W, C. Estrella, May 1953. MEPN-17049, 1 ex., 60.6 mm SL, Río Jujan, cerca de la población de Jujan, approx. 01 ${ }^{\circ} 53^{\prime} 04 \mathrm{~S}$ 79³3'06"W, S. Abril, 23 June 1986. MEPN-17050, 1 ex., $84.8 \mathrm{~mm}$ SL, Quevedo, G. Onore, November 1983. MEPN-18151, 3 ex., 192.3-213.4 mm SL, Río Las Juntas, afluente del río Babahoyo, approx. 0152'06"S 79²2'43"W, M. Olalla, 12 March 1964. Manabí Province, MEPN-9099, 1 ex., 135.6 mm SL, Río Portoviejo, Laguna de Poza Honda, parte inferior, approx., 0104'55"S 8009'16"W, R. Barriga, 05 February 1993. MEPN-17952, 6 ex., 56.3-183.9 mm SL, Río Portoviejo, $1 \mathrm{~km}$ aguas abajo de la primera compuerta, approx., 0106'21"S 8009'41"W, R. Barriga et al., 03 October 1992.

Hemiancistrus landoni is recognized among all species of Hemiancistrus sensu lato, except for H. medians by its abdomen, which is completely covered by small bony plates, and has a peculiar color pattern, rounded dark spots ( $v s$. abdomen naked with light spots or plain). According to the figures and redescription indicated by FischMuller et al. (2012), H. landoni can be recognized from H. medians, by its dorsal fin when folded does not reach the origin of the adipose fin versus the dorsal fin folded reaches the origin of the adipose fin. Further recognized by its head shape, which is less deep, and by its supraoccipital without a keel. In H. medians, the head is massive, and the supraoccipital has a keel. The eye is smaller in H. landoni than in H. medians, $15 \%-16 \%$ HL versus $18 \%-27 \%$ HL, respectively. Finally, the number of cheek odontodes is smaller in H. landoni than in H. medians, 10-20 vs. 20-60. Some large specimens show highly developed, long and pointed odontodes, on distal and dorsal portion of pectoral spines. This condition, as in other cases, may occur in sexually active adult males. Hemiancistrus landoni is an endemic species of the Pacific slope of Ecuador, and is found exclusively in aquatic systems of the Guayas River Basin and other water courses related to this basin.

Comparative osteology. On the three species identified, we examined the bones that are related to the mobility of the opercular bone. The bones are the sphenotic, the compound pterotic (from now the pterotic), the hyomandibular and the opercular. The observed changes in the state or condition of each bone are related to the development of the musculature involved in the movement of the opercular and concomitant of the developed odontodes associated. 
The observed changes on the sphenotic occur on the posterior surface. Two conditions are perceived; in the first condition, the posterior region has an excavation or canal, extending from the middle of the bone to the ventral region of the bone; the area from the middle of the bone towards the dorsal region is massive (Fig. 6A). The second condition is an excavation or canal that runs along the entire posterior surface, from the dorsal to the ventral. This channel is open in the ventral region, but towards the dorsal border it may be totally or partially open (Fig. 6B). In $H$. annectens the first condition is observed, while in $H$. landoni and in $H$. furtivus, the second condition is observed, the canal is almost occluded at the dorsal border.

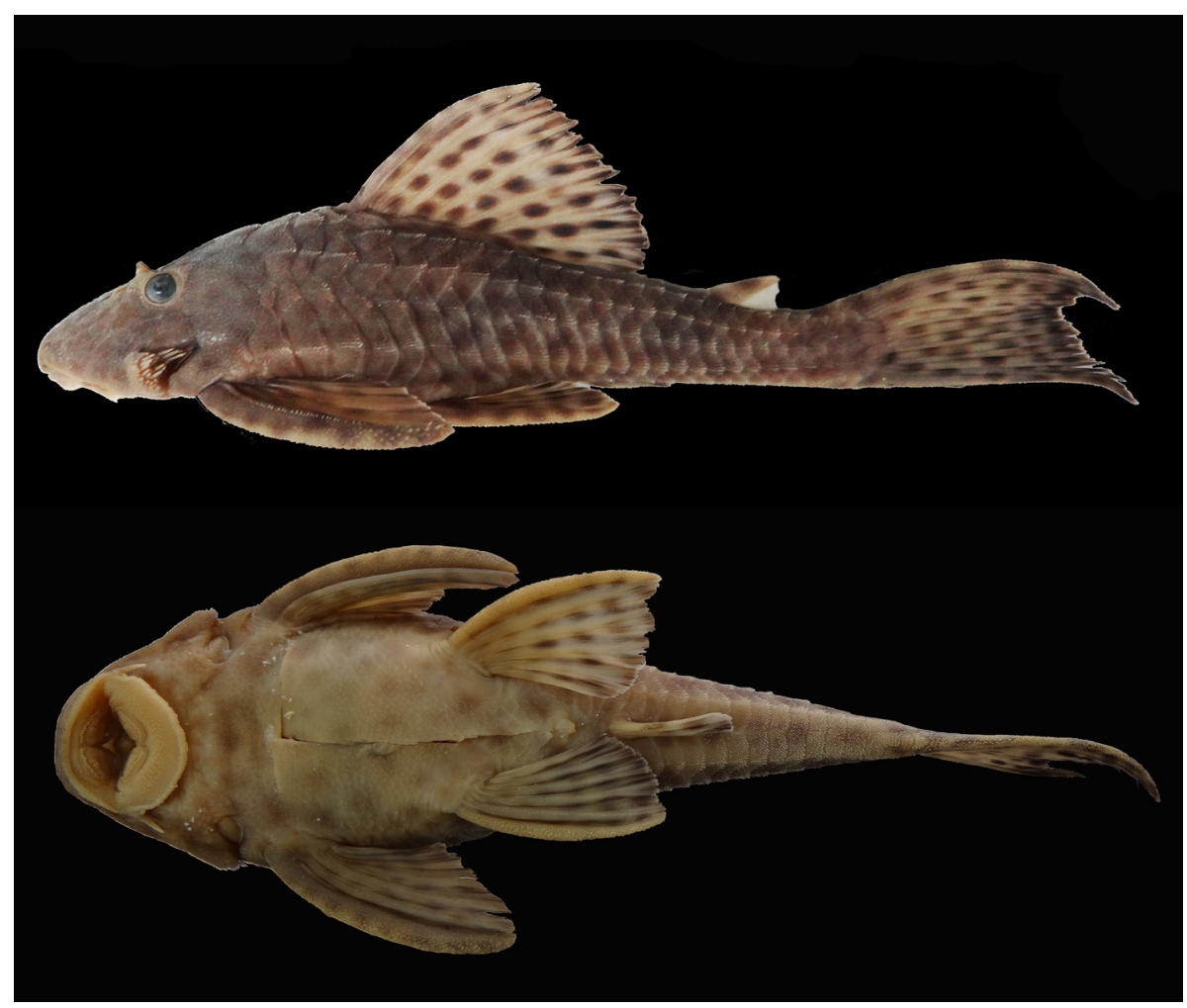

FIGURE 4. Lateral and ventral view of Hemiancistrus landoni, MEPN 17952, 135.4 mm SL.

The pterotic bone has on its anterior surface something similar to that indicated for the sphenotic. In the first condition we can observe the presence of a canal that is occluded or closed towards the dorsal region of the bone (Fig. 7A). In the second condition the canal runs all or nearly all of the entire anterior surface of the pterotic bone (Fig. 7B). By articulating the sphenotic and pterotic bones, the canal partially becomes a tunnel. The tunnel may be closed or open dorsally. In $H$. annectens, the first condition is observed, the pterotic canal is occluded or the tunnel is closed. In H. landoni and in H. furtivus, the second condition is observed, here the channel and tunnel runs almost all the anterior surface of the pterotic and the posterior surface of the sphenotic. In this case the tunnel closes towards the dorsal region.

On the ventral and anterior border of the pterotic there is a fossa and a process (anterior process of the pteroticsupracleitrum according to Armbruster 2004). Again, two conditions related to this region are observed. In the first condition, the fossa and the process are slightly developed (Fig. 7A). In the second, there is an appreciable development of the fossa and the process (Fig. 7B). In H. annectens, the first condition is observed, while in $H$. landoni and in $H$. furtivus, the second condition is observed.

On the analyzed species, the opercular bone presents two different forms (Fig. 8). In the first condition, the general shape or contour of the bone is almost triangular, similar to that described by Schaefer (1987) for Hypostomus plecostomus and Cochlidon cochliodon and Armbruster (2004) for Hemiancistrus maracaiboensis and Hypostomus taphorni (condition 0). In the second condition, the opercular has the contour of the opercular in the form of a paddle with a posterior dorsal projection, similar to that described by Schaefer (1987) for Peckoltia niveata and by Armbruster (2004) for Peckoltia sp. (Condition 1, Type-Peckoltia). The first condition of the opercular is present in H. annectens (Fig. 8A), while the second condition is observed in H. landoni and H. furtivus 
(Fig. 8B). The changes in opercular shape can be related to the increase in its rotational capacity at the point of support (condyle of articulation with the hyomandibular) and its properties as a lever. The conditions or states observed could be used to include the species under study into the Hypostomini or Ancistrini sensu Armbruster (2004).

The changes noted in the three bones are linked to increased development (increased diameter or muscle thickness) and increased surfaces of origin and insertion of the levator operculi and dilator operculi muscles, which was evidenced during the preparation of skeletons.

Discussion. The status of the genus Hemiancistrus is still controversial. The loss of the holotype of $H$. medians, and the way Kner (1854) presented the original description, generated doubts and discrepancies about the correct identity of this species. Fisch-Muller et al. (2012) established the taxonomic status and the identity of the type species, in spite of the descriptions provided by Günther (1864) and Regan (1904). We do not have specimens of $H$. medians, however, as indicated by Fisch-Muller et al. (2012) and Armbruster et al. (2015), H. medians and $H$. landoni share some external morphological characteristics not observed in the other species included in Hemiancistrus sensu lato, such as the presence of keels in the lateral plates of the body and a similar coloration pattern. The way the abdomen is covered appears to have some difference between $H$. medians and $H$. landoni, but none of the other species included in the group has such an extended abdominal covering. According with Armbruster et al. (2015) only H. medians is included in the genus Hemiancistrus. Therefore, the generic status of $H$. landoni and the other species remains uncertain.

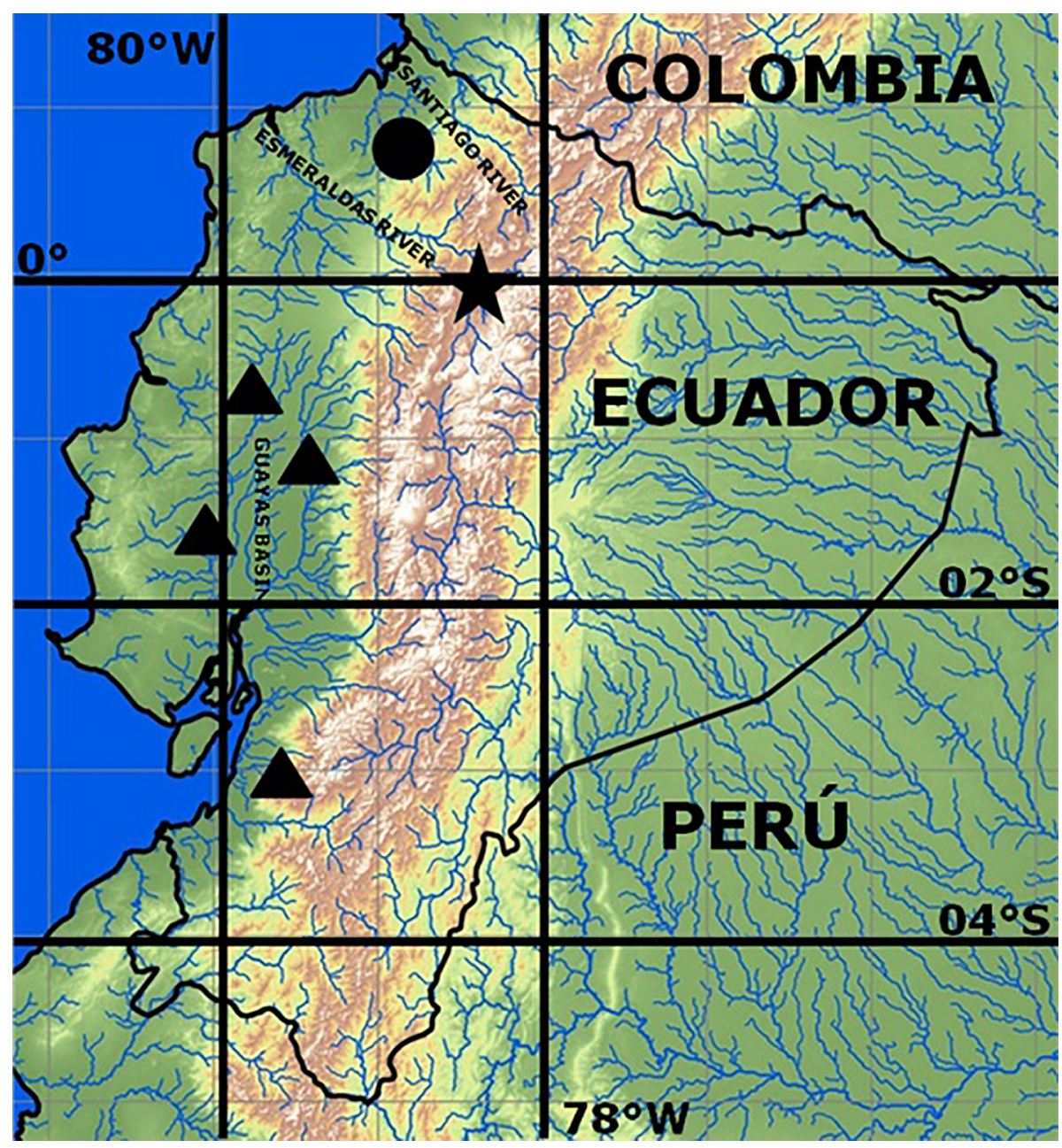

FIGURE 5. Geographical distribution of Hypostomus annectens (circle), Hemiancistrus furtivus (star), and Hemiancistrus landoni (triangle). Symbols may represent more than one lot. 


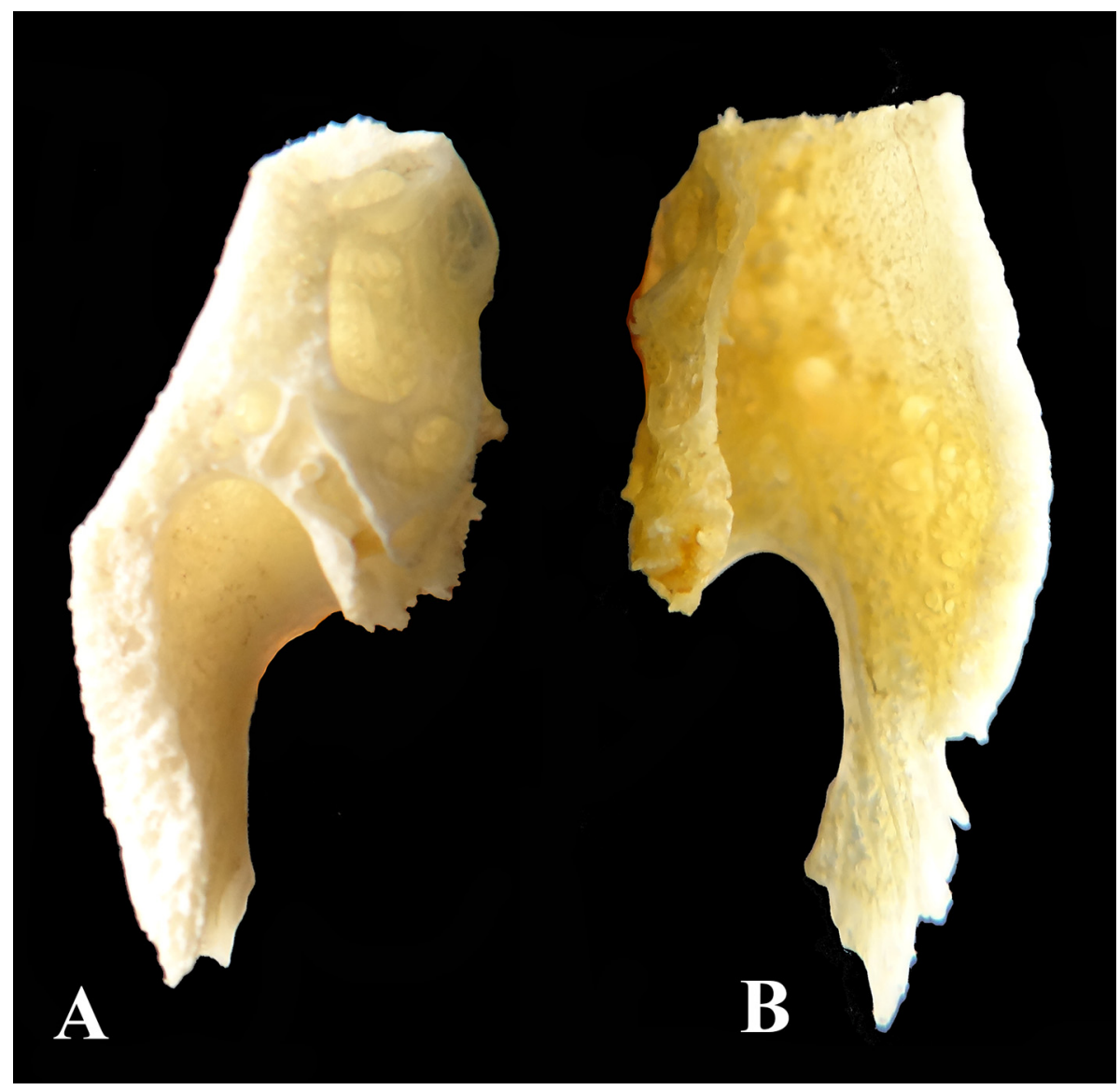

FIGURE 6. Posterior view of sphenotic. A) Hypostomus annectens, specimen of $190.0 \mathrm{~mm} \mathrm{SL}$, left, and B) Hemiancistrus landoni, specimen of about $210.0 \mathrm{~mm} \mathrm{SL}$, without data, right.

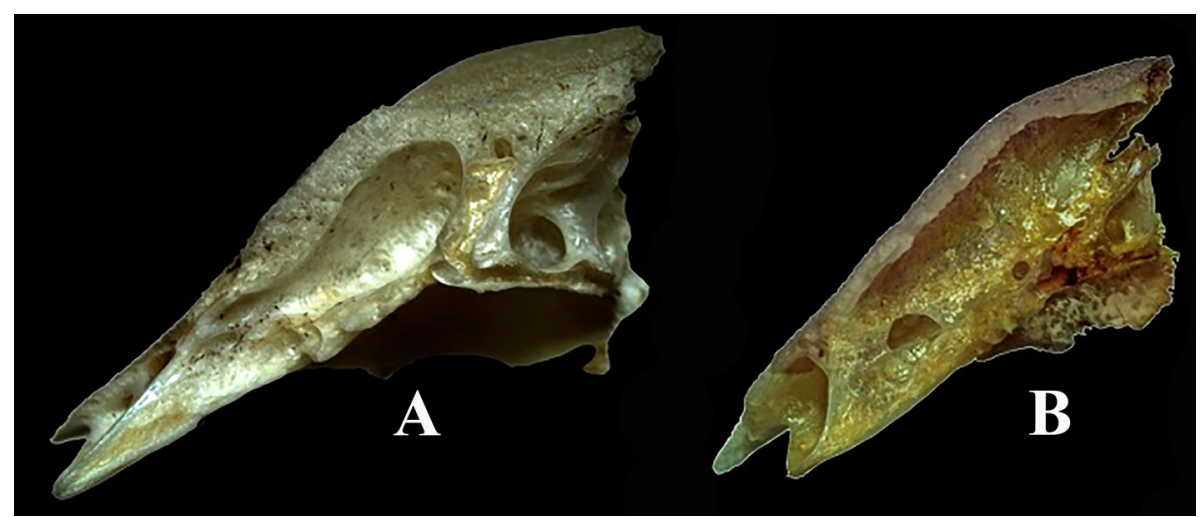

FIGURE 7. Frontal view of right pterotic. A) Hypostomus annectens, specimen of $190.0 \mathrm{~mm}$ SL, and B) Hemiancistrus landoni, specimen of about $210.0 \mathrm{~mm} \mathrm{SL}$, without data.

Hemiancistrus furtivus is represented at the MEPN by seven specimens in five cataloged lots. Only four are in good conditions, and/or with an appreciable standard length. Comparisons with original descriptions of the geographically nearest species were made carefully, and the external characters observed on H. furtivus shows that it is a new species. The belly is totally naked, the dorsal and caudal fins have a distinctive color pattern, and the small movable cheek odontodes differ from that of other Pacific Coast species described or placed in Hemiancistrus. In spite of this, the body color pattern observed on our specimens is very close with that reported by Eigenmann (1916) in the original description of H. landoni. He pointed out that the body has four oblique transverse saddles, the first behind the eyes, the second at the end of the dorsal fin, the third at the level of adipose fin, and the fourth at the caudal-fin origin. On our specimens of $H$. landoni, the presence of saddles is variable in 
that some are very evident while in others they are very faint or no traces are observed (Fig. 2). Two more species, were originally described from the Pacific versant of Ecuador, H. hammarlundi Rendahl 1937, and H. fugleri Ovchynnyk 1971. We agree with they are synonymous with $H$. landoni and $H$. annectens, respectively. The original description of $H$. hammarlundi was made on a unique specimen of $70.4 \mathrm{~mm}$ SL (Armbruster per. comm.). This specimen has small patches of granular plates on belly, and 20 movable odontodes developed in the cheek area. This is clearly different to that observed in H. furtivus. On the other hand, Ovchynnyk (1971) in the original description of $H$. fugleri, points out that the folded dorsal fin reaches or is very close to adipose-fin origin, and that the belly has small patches of granular plates. The specimen used was $91 \mathrm{~mm}$ SL. Only the examined juveniles of $H$. annectens show that the folded dorsal fin reaches the adipose-fin origin, and they also have small patches of granular plates on belly. The first character is useful to distinguish juveniles from $H$. landoni and $H$. furtivus, but the character changes with size; in large specimens of the three species, the folded dorsal fin does not reach the adipose-fin origin. Also, the figures provided by Ovchynnyk (1971) show a color pattern of the body and fins similar to $H$. annectens, and different to that observed in H. furtivus. Additionally, there are no developed cheek odontodes in H. fugleri. These results support the synonymy proposed by Armbruster et al. (2015) between the species previously described from Ecuador, and confirms the presence of the new species. The completely naked abdomen, the dark rounded dots on it, and the small movable cheek odontodes distinguish $H$. furtivus from all other species included in Hemiancistrus sensu lato (Armbruster et al. 2015). Finally, Armbruster et al. (2015) established at least three groups within Hemiancistrus sensu lato. The groupings are based on morphological similarity of species. The species H. landoni and H. furtivus are similar in overall body shape and the color pattern, but the cover of the abdomen and the degree development of mobile cheek odontodes are different. Despite these facts both species are included in the H. landoni group.

Hemiancistrus annectens, H. aspidolepis, H. maracaiboensis, H. holostictus and H. wilsoni, inhabit the transAndean region, Panamá, Maracaibo lake basin, the rivers Magdalena, Cauca, Atrato, San Juan (Colombia), and Santiago (Ecuador). When comparing the original descriptions of all species, and specimens of H. annectens, it is evident that the external morphology, the meristic and morphometric data, and the color pattern are similar. This fact was previously detected by Schultz (1944), and mentioned by Regan (1913) and Eigenmann (1918). Some morphometric differences can be related with the size, the fixation and preservations conditions of the type specimens. At this moment, we do not have specimens of the other species on hand, and we are unable to offer diagnostics characters to recognize each species. A study to establish the status of each species is necessary, using direct comparison of fresh and well preserved specimens from each basin. In the meantime, the use of the names proposed to each basin is suggested. Recently, Armbruster et al. (2015) reassign to the genus Hypostomus the five species, as a consequence of the results obtained on phylogenetic analyses. The external morphology of the five trans-Andean species of Hypostomus seems to indicate that they do not belong in the genus Hemiancistrus or even to the Ancistrini group, as pointed in morphological and molecular phylogenies (Armbruster 2004, 2008; Lujan et al 2015).

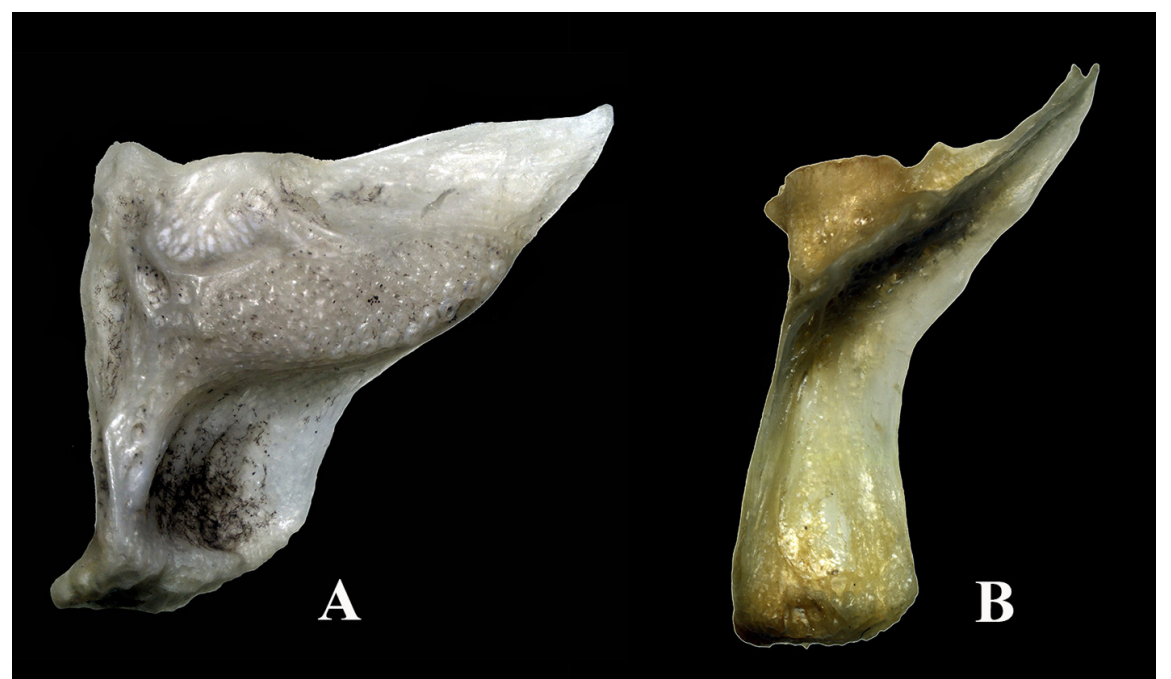

FIGURE 8. External lateral view of right opercular. A) Hypostomus annectens, specimen of $190.0 \mathrm{~mm} \mathrm{SL}$, and B) Hemiancistrus landoni, specimen of about $210.0 \mathrm{~mm} \mathrm{SL}$, without data. 
The comparative analysis of the bones related to the movement of the opercular, support the placement of $H$. annectens in the Hypostomini and H. landoni and H. furtivus in the Ancistrini. In order to establish the proper generic allocation of $H$. annectens a project is being carried out which includes a comparative analysis of the indicated bones, between this species and species traditionally included in the genus Hypostomus. In an analogous way, it is hoped to be able to compare osteologically the species included in the genus Hemiancistrus sensu lato to indicate its appropriate taxonomic status.

\section{Acknowledgements}

We are grateful to Proyecto Prometeo, Secretaría de Educación Superior, Ciencia, Tecnología e Innovación, Ecuador, and Instituto de Ciencias Biológicas, Escuela Politécnica Nacional. Thanks to Jonathan Armbruster (Auburn University) for a critical review of the manuscript; Karsten E. Hartel and Andrew Williston (MCZ Harvard University) for its support in the analysis and prepare images and CT of paratypes specimens MCZ 48772; Pedro Jiménez (PUCE, Esmeraldas Province) who gave us some specimens of H. annectens, and to Vladimir Carvajal López (Instituto de Ciencias Biologicas, EPN) who took photos of bones.

\section{References}

Armbruster, J.W. (2004) Phylogenetic relationships of the suckermouth armored catfishes (Loricariidae) with emphasis on the Hypostominae and Ancistrinae. Zoological Journal of the Linnaean Society, 141 (1), 1-80. https://doi.org/10.1111/j.1096-3642.2004.00109.x

Armbruster, J.W. (2008) The genus Peckoltia with the description of two new species and a reanalysis of the phylogeny of the genera of the Hypostominae (Siluriformes: Loricariidae). Zootaxa, 1822, 1-76.

Armbruster, J.W., Werneke, D.C. \& Tan, M. (2015) Three new species of saddled loricariid catfishes, and a review of Hemiancistrus, Peckoltia, and allied genera (Siluriformes). ZooKeys, 480, 97-123. https://doi.org/10.3897/zookeys.480.6540

Bleeker, P. (1862) Atlas ichthyologique des Indes Orientales Nèêrlandaises, publiè sous les auspices du Gouvernement colonial nèêrlandaises. Tome II. Siluroîdes, Chacoîdes et Hètèrobranchoîdes. Muller, Amsterdam, 112 pp, pls. 49-101. https://doi.org/10.5962/bhl.title.67474

Boeseman, M. (1968) The genus Hypostomus Lacépède, 1803, and its Surinam representatives (Siluriformes, Loricariidae). Zoologische Verhandelingen, 99, 1-89.

Cardoso, A.R. (2004) Hemiancistrus megalopteryx, a new species of loricarid catfish from the rio Tubarão drainage, Santa Catarina State, Brazil. Ichthyological Exploration of Freshwaters, 15 (2), 173-178.

Cardoso, A.R. \& Lucinda, P.H.F. (2003) Three new species of Hemiancistrus (Teleostei: Siluriformes: Loricariidae) from the rio Tocantins basin with comments on the genus. Ichthyological Exploration of Freshwaters, 14 (1), $73-84$.

Cardoso, A.R. \& Malabarba, L.R. (1999) Description of three new species of Hemiancistrus Bleeker, 1862 from southern Brazil (Teleostei: Siluriformes: Loricariidae). Comunicaçôes do Museu de Ciências e Technologia PUCRS Série Zoologia, Porto Alegre, 12, 141-161.

Cardoso, A.R. \& Pezzi da Silva, J.F. (2004) Two new species of the genus Hemiancistrus Bleeker (Teleostei: Siluriformes: Loricariidae) from the upper rio Uruguai basin. Neotropical Ichthyology, 2 (1), 1-8. https://doi.org/10.1590/s1679-62252004000100001

Covain, R. \& Fisch-Muller, S. (2012) Molecular evidence for the paraphyly of Pseudancistrus sensu lato (Siluriformes, Loricariidae), with revalidation of several genera. Cybium, 36 (1), 229-246.

Eigenmann, C.H. (1910) Catalogue of the fresh-water fishes of tropical and south temperate America. Reports of the Princeton University expeditions to Patagonia 1896-1899. Zoology, 3 (4), 375-511.

Eigenmann, C.H. (1916) New and rare fishes from South American rivers. Annals of the Carnegie Museum, 10 (1-2), 77-86, pls. $13-16$.

Eigenmann, C.H. (1918) Eighteen new species of fishes from northwestern South America. Proceedings of the American Philosophical Society, 56 (7), 673-689.

Fisch-Muller, S. (2003) Subfamily Ancistrinae. In: Reis, R.E. Kullander, S.O. \& Ferraris Jr., C.J. (Ed.), Check List of the Freshwater Fishes of South and Central America. EDIPUCRS, Porto-Alegre, pp. 373-400.

Fisch-Muller, S., Montoya-Burgos, J.I., Le Bail, P.-Y. \& Covain, R. (2012) Diversity of the Ancistrini (Siluriformes: Loricariidae) from the Guianas: the Panaque group, a molecular appraisal with descriptions of new species. Cybium, 36 (1), 163-193.

Günther, A. (1864) Catalogue of the Fishes in the British Museum. Vol. 5. Catalogue of the Physostomi, Containing the Families Siluridae, Characinidae, Haplochitonidae, Sternoptychidae, Scopelidae, Stomiatidae in the Collection of the 
British Museum. Trustees, London, xxii $+455 \mathrm{pp}$.

Günther, A. (1867) Memoir on the fishes of the states of Central America, founded upon specimens collected in fresh and marine waters of various parts of that country by Messrs. Salvin and Godman and Capt. J. M. Dow. Proceedings of the Zoological Society of London, 1866 (3), 600-604.

Isbrücker, I.J.H. (1980) Classification and catalogue of the mailed Loricariidae (Pisces, Siluriformes). Verslagen en Technische Gegevens, Instituut voor Taxonomische Zoölogie, Universiteit van Amsterdam, 22, 1-181.

Kner, R. (1854) Die Hypostomiden. Zweite Hauptgruppe der Familie der Panzerfische. (Loricata vel Goniodontes). Denkschriften der Mathematisch- Naturwissenschaftlichen Classe der Kaiserlichen Akademie der Wissenschaften in Wien, 7, 251-286, pls. 1-5.

Lujan, N.K. \& Chamon, C.C. (2008) Two new species of Loricariidae (Teleostei: Siluriformes) from main channel of the upper and middle Amazon Basin, with discusion of deep water specialization in loricariids. Ichthyological Exploration of Freshwaters, 19 (3), 271-282.

Lujan, N.K., Armbruster, J.W., Lovejoy, N. \& López-Fernández, H. (2015) Multilocus molecular phylogeny of the suckermouth armored catfishes (Siluriformes: Loricariidae) with a focus on subfamily Hypostominae. Molecular Phylogenetics and Evolution, 62, 269-288.

https://doi.org/10.1016/j.ympev.2014.08.020

Ovchynnyk, M.M. (1971) Unrecorded and new species of fishes from fresh waters of Ecuador. Zoologischer Anzeiger, 187 (12), 82-122.

Provenzano, F. \& Nass, P. (2017) On the preparation of vertebrate skeletons using pancreatic enzyme digestion of formalinfixed specimens. [in preparation]

Regan, C.T. (1904) A monograph of the fishes of the family Loricariidae. Transactions of the Zoological Society of London, 17 (3), 191-350, pls. 9-21. https://doi.org/10.1111/j.1096-3642.1904.tb00040.x

Regan, C.T. (1913) The fishes of the San Juan River, Colombia. Annals and Magazine of Natural History, Series 8, 12 (71), 462-473. https://doi.org/10.1080/00222931308693424

Rendahl, H. (1937) Einige Fische aus Ecuador und Bolivia. Arkiv för Zoologi, 29 (3), A (11), 1-11.

Schaefer, S.A. (1987) Osteology of Hypostomus plecostomus (Linnaeus), with a phylogenetic analysis of the loricariid subfamilies (Pisces: Siluroidei). Contributions in Science, Natural History Museum of Los Angeles County, 394, 1-31.

Schultz, L.P. (1944) The catfishes of Venezuela, with descriptions of thirty-eight new forms. Proceedings of the United States National Museum, 94 (3172), 173-338, pls. 1-14.

de Souza, L.S., Melo, M.R.S., Chamon, C.C. \& Armbruster, J.W. (2008) A new species of Hemiancistrus from the rio Araguaia basin, Goiás state, Brazil (Siluriformes: Loricariidae). Neotropical Ichthyology, 6 (3), 419-424. https://doi.org/10.1590/s1679-62252008000300015

Werneke, D.C., Armbruster, J.W., Lujan, N.K. \& Taphorn, D.C. (2005) Hemiancistrus guahiborum, a new suckermouth armored catfish from southern Venezuela (Siluriformes: Loricariidae). Neotropical Ichthyology, 3 (4), 543-548. https://doi.org/10.1590/s1679-62252005000400012

Werneke, D.C., Sabaj Pérez, M.H., Lujan, N.K. \& Armbruster, J.W. (2005) Baryancistrus demantoides and Hemiancistrus subviridis, two new uniquely colored species of catfishes from Venezuela (Siluriformes: Loricariidae). Neotropical Ichthyology, 3 (4), 533-542.

https://doi.org/10.1590/s1679-62252005000400011 